\title{
KORELACJA ZMIAN STĘŻEŃ PYŁÓW ZAWIESZONYCH PM10 Z TYPAMI CYRKULACJI ATMOSFERYCZNEJ W KONINIE W LATACH 2012-2016
}

\author{
KAJA KARCZEWSKA, LESZEK KOLENDOWICZ, MAREK PÓŁROLNICZAK, \\ HANNA FORYCKA-ŁAWNICZAK \\ Uniwersytet im. Adama Mickiewicza w Poznaniu, \\ Wydział Nauk Geograficznych i Geologicznych, Zakład Klimatologii \\ ul. B. Krygowskiego 10, 61-680 Poznań
}

\begin{abstract}
The subject of the paper is the influence of atmospheric circulation on the content of suspended PM10 in the air in Konin. For this purpose dust concentrations from the period 2012-2016 were generally characterized. PM10 particulate matter concentration average hourly data were obtained from the Main Inspectorate of Environmental Protection website. Based on these data, long-term, seasonal and daily changes in the PM10 concentration in the atmosphere were investigated. The study analysed the daily variability of the PM10 suspended particulate matter concentration to present seasonal differences (in hot and cold seasons). In order to determine the influence of atmospheric circulation on the PM10 particulate matter concentration, the concentration levels data were compared with the types of circulation prevailing on the same day. In this study according to synoptic maps the days with maximum and minimum concentrations PM levels were analysed. It was found which type of meteorological circulation is conducive to higher levels concentrations of particulate matter PM10, and which has a positive effect on the quality of the air in Konin.
\end{abstract}

Keywords: particulate matter PM10, atmospheric circulation, concentration levels analysis, Konin, Poland.

\section{WSTĘP}

Pył zawieszony w powietrzu to mieszanina cząstek organicznych i nieorganicznych na tyle małych, że nie opadają na powierzchnię ziemi, lecz są w stanie utrzymywać się w atmosferze. Pył ten może zawierać substancje toksyczne, np. metale ciężkie, benzo(a)piren, furany oraz dioksyny. W literaturze mówi się o dwóch rodzajach pyłów zawieszonych: PM10 i PM2,5 (PM - particulate matter - pył zawieszony). Różnią się one średnicą ziaren oraz wpływem na organizm człowieka.

Pył PM10 jest mniej szkodliwy, ponieważ jego cząstki są na tyle duże (średnica większa od 10 mikrometrów), że mogą zostać wydalone z płuc i gromadzą się jedynie w górnych drogach oddechowych człowieka. Mają więc utrudnioną drogę do krwioobiegu w przeciwieństwie do cząstek pyłu PM2,5 (średnica mniejsza niż 2,5 mikrometra), które są w stanie nie tylko dostać się do górnych dróg oddechowych, ale także do płuc, skąd nie mogą być wydalone. Pył zalegający w płucach $\mathrm{z}$ łatwością dostaje się do krwioobiegu i powoduje różnego rodzaju choroby (Cembrzyńska $\mathrm{i}$ in. 2012). 
Wyróżnia się dwa rodzaje źródeł pyłów zawieszonych. Są to źródła antropogeniczne i naturalne. Pyły pochodzenia antropogenicznego to przede wszystkim zanieczyszczenia emitowane wskutek procesów spalania paliw kopalnych, w procesach produkcji przemysłowej, komunikacji oraz w lokalnych kotłowniach i przydomowych piecach grzewczych (Fuksa, Cieszyńska 2010). Do źródeł pyłów pochodzenia naturalnego zalicza się pożary lasów powstałe bez ingerencji człowieka, wybuchy wulkanów i aerozole morskie. Pyły zawieszone pochodzenia naturalnego dostają się do atmosfery również w wyniku wietrzenia skał osadowych i gleby.

W Rozporządzeniu Ministra Środowiska z dnia 24 sierpnia 2012 r. w sprawie niektórych substancji w powietrzu (Dz.U. z 2012 r., poz. 1031) przedstawiono dopuszczalne stężenia PM10 i PM2,5. Określono w nim m.in. dopuszczalny poziom stężenia PM10 średniodobowego, tj. $50 \mu \mathrm{g} / \mathrm{m}^{3}$, który może zostać przekroczony maksymalnie do 35 razy w ciągu roku. Dla stężenia średniorocznego określono poziom dopuszczalny wynoszący $40 \mu \mathrm{g} / \mathrm{m}^{3}$. Rozporządzenie określa również poziom informowania oraz poziom alarmowy w przypadku stężenia 24-godzinnego. Poziom informowania wyznacza wartość stężenia PM10 w wysokości $200 \mu \mathrm{g} / \mathrm{m}^{3}$, poziom alarmowy zaś wynosi $300 \mu \mathrm{g} / \mathrm{m}^{3}$.

W przypadku PM2,5 w rozporządzeniu przedstawiono mniej obostrzeń niż dla PM10. Określono jedynie poziom dopuszczalny stężenia średniorocznego wynoszący $25 \mu \mathrm{g} / \mathrm{m}^{3}$, który do roku 2020 ma zostać obniżony do $20 \mu \mathrm{g} / \mathrm{m}^{3}$ (GIOŚ, 2017; <www.powietrze.gios.gov.pl>).

Stopień zanieczyszczenia powietrza w dużej mierze kształtowany jest również przez warunki meteorologiczne. Ciśnienie atmosferyczne, prędkość i kierunek wiatru, opady, wilgotność względna powietrza oraz natężenie promieniowania słonecznego mają duży wpływ na stężenie PM10 (Gioda i in. 2013). Im niższa temperatura i słabsze oddziaływanie wiatru, tym koncentracja pyłu zawieszonego w powietrzu jest większa (Chlebowska-Styś, Sówka 2015). W sytuacjach wyżowych obniżenie przyziemnej warstwy mieszania prowadzi do większej koncentracji pyłów. Z kolei niższą koncentrację pyłu zawieszonego 10 odnotowuje się podczas wystąpienia opadu atmosferycznego. Wysoka wilgotność powietrza sprzyja agregacji cząstek pyłu i szybszej depozycji (Ćwiek, Majewski 2015; Oleniacz i in. 2014; Czarnecka, Kalbarczyk 2008).

Istotny dla jakości powietrza jest stan równowagi w dolnej części warstwy granicznej atmosfery, gdzie podczas występowania równowagi stałej dochodzi do ograniczenia dyspersji zanieczyszczeń (Drzeniecka-Osiadacz, Netzel 2010). Warunki sprzyjające ich akumulacji pojawiają się najczęściej zimą w przypadku cyrkulacji związanej z ośrodkiem wysokiego ciśnienia (Drzeniecka i in. 2000; Leśniok i in. 2010).

Z badań podejmowanych przez wielu autorów wynika, że cyrkulacja atmosfery jest jednym z głównych czynników kształtujących klimat. Odgrywa ona istotną rolę w modyfikacji warunków klimatycznych w obszarach zurbanizowanych 
i przemysłowych, a także wpływa na koncentrację lub dyspersję zanieczyszczeń. Zależnie od występowania określonych układów barycznych i mas powietrza nasila się bądź słabnie oddziaływanie czynnika antropogenicznego, a tym samym poziom zanieczyszczenia atmosfery (Niedźwiedź 1999; Radomski 2008).

W niniejszym opracowaniu podjęto próbę ustalenia powiązań intensywności stężenia PM10 z typami cyrkulacji atmosfery według T. Niedźwiedzia (2006) sporządzonych dla Polski.

\section{DANE ŹRÓDŁOWE I METODY BADAŃ}

Celem pracy jest przedstawienie zależności stężenia PM10 od typów cyrkulacji atmosferycznej występujących na obszarze Konina, dlatego dokonano porównania średnich dobowych wartości stężenia PM10 z rodzajem cyrkulacji atmosferycznej oddziałującej na badany obszar.

Dane pomiarowe dotyczące stężenia PM10 uzyskano ze zautomatyzowanej stacji pomiarowej Wojewódzkiego Inspektoratu Ochrony Środowiska znajdującej się w Koninie przy ul. Wyszyńskiego. Dokonuje się na niej pomiarów m.in. PM10 w celu ochrony zdrowia ludzi (ryc. 1). Jest to kontenerowa stacja pomiarowa pozyskująca dane średnich stężeń pyłu zawieszonego 10, a wykorzystuje do tego automatyczną metodę pomiarów, stosując przy tym jednogodzinny czas uśredniania.

$\mathrm{Na}$ podstawie danych pomiarowych $\mathrm{z}$ tej stacji dokonano uśrednienia godzinowych stężeń pyłów zawieszonych w powietrzu PM10 we wszystkich dobach $\mathrm{z}$ określonym typem cyrkulacji atmosferycznej. Następnie obliczono odpowiednio średnie wartości stężeń miesięcznych i sezonowych charakterystyczne dla wszystkich typów cyrkulacji.

Informację o zawartości i jakości danych źródłowych przedstawiono $\mathrm{w}$ tabeli 1 . Najwyższe wartości

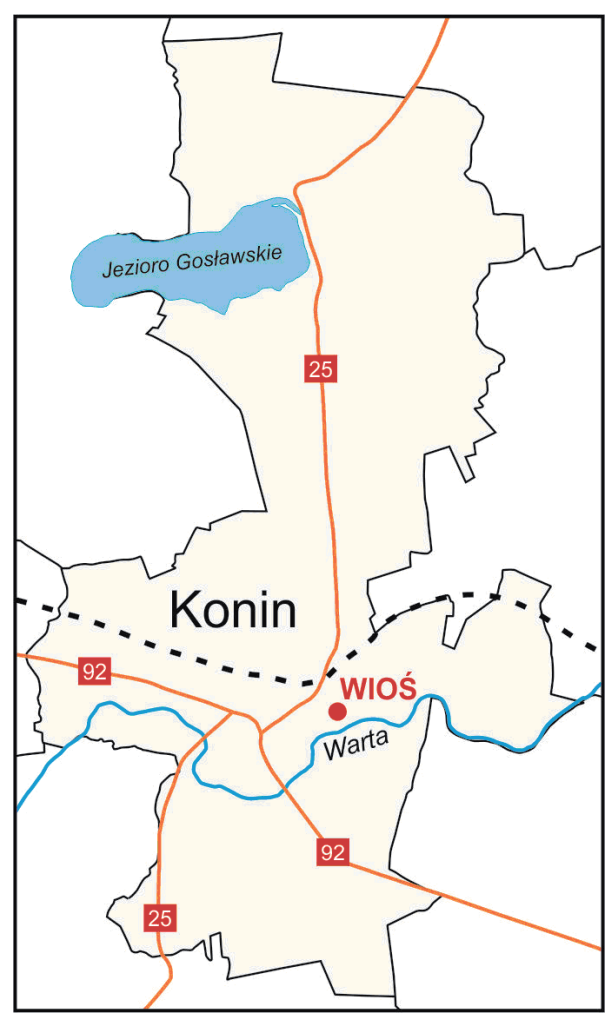

Ryc. 1. Położenie stacji pomiaru stężenia PM10 w Koninie

Fig. 1. Location of the PM10 concentration measurement station in Konin 
stężenia PM10 (klasa $140<x \leq 160$ ) zostały osiągnięte jedynie w $0,1 \%$ wszystkich przypadków, natomiast najniższe wartości (klasa $0<x \leq 20$ ) w 34,1\%. Najczęściej występowały wartości stężeń w granicach klasy $20<x \leq 40(43,7 \%$ ogółu przypadków), najrzadziej zaś odnotowano stężenia zawarte w klasie 120 $<\mathrm{x} \leq 140(0,05 \%$ ogółu przypadków). W tabeli 1 zaznaczono również procent przypadków $(1,84 \%)$, który stanowiły braki danych.

Tabela 1. Tabela liczności dla wartości stężeń PM10 $\left[\mu \mathrm{g} / \mathrm{m}^{3}\right]$ w Koninie w latach 2012-2016

Table 1. Table of quantities for PM10 dust concentrations $\left[\mu \mathrm{g} / \mathrm{m}^{3}\right]$ in Konin in 2012-2016

\begin{tabular}{lrrrrrr}
\hline \hline \multicolumn{1}{c}{ Klasa } & Liczba & $\begin{array}{c}\text { Skumulo- } \\
\text { wana } \\
\text { liczba }\end{array}$ & $\begin{array}{c}\text { Procent } \\
\text { ważnych }\end{array}$ & $\begin{array}{c}\text { Skumulo- } \\
\text { wany \% } \\
\text { ważnych }\end{array}$ & $\begin{array}{c}\% \text { ogółu } \\
\text { przypad- } \\
\text { ków }\end{array}$ & $\begin{array}{c}\text { Skumulo- } \\
\text { wany \% } \\
\text { ogółu }\end{array}$ \\
\hline $0<x \leq 20$ & 629 & 629 & 34,80908 & 34,8091 & 34,16621 & 34,1662 \\
$20<x \leq 40$ & 805 & 1434 & 44,54898 & 79,3581 & 43,72624 & 77,8924 \\
$40<x \leq 60$ & 228 & 1662 & 12,61760 & 91,9757 & 12,38457 & 90,2770 \\
$60<x \leq 80$ & 94 & 1756 & 5,20199 & 97,1776 & 5,10592 & 95,3829 \\
$80<x \leq 100$ & 41 & 1797 & 2,26895 & 99,4466 & 2,22705 & 97,6100 \\
$100<x \leq 120$ & 7 & 1804 & 0,38738 & 99,8340 & 0,38023 & 97,9902 \\
$120<x \leq 140$ & 1 & 1805 & 0,05534 & 99,8893 & 0,05432 & 98,0445 \\
$140<x \leq 160$ & 2 & 1807 & 0,11068 & 100,0000 & 0,10864 & 98,1532 \\
Braki & 34 & 1841 & 1,88157 & & 1,84682 & 100,0000 \\
\hline
\end{tabular}

Dane opisujące typy cyrkulacji atmosferycznej zaczerpnięto z kalendarza typów cyrkulacji atmosfery dla Polski południowej. Kalendarz został opracowany przez T. Niedźwiedzia (2006), który zaproponował 21 typów cyrkulacji atmosferycznej dla obszaru Polski (tab. 2). Do każdego typu cyrkulacji przypisano numer od 1 do 21 . Pierwsze 10 to typy antycyklonalne, czyli kształtowane przez wyż baryczny, w drugiej dziesiątce zaś znajdują się typy cyklonalne powstałe w skutek oddziaływania niżu. Numerem 21 oznaczono niesklasyfikowaną sytuację synoptyczną.

W kolejnej części opracowania wyznaczono 1. i 99. percentyl ze średnich dobowych wartości całego zbioru danych w celu wyszczególnienia ekstremalnych wartości stężenia pyłów zawieszonych PM10 i skorelowania ich z panującymi w tych dniach typami cyrkulacji atmosferycznej. Następnie dla dni, w których występowały najwyższe (wyższe od 99. percentyla) i najniższe (niższe od 1. percentyla) stężenia PM10, pobrano mapy synoptyczne $<$ wetter3.de $>$ w celu określenia sytuacji meteorologicznej odpowiadającej wartościom ekstremalnym. 
Tabela 2. Typy cyrkulacji atmosferycznej według T. Niedźwiedzia (2017)

Table 2. List of circulation types after T. Niedźwiedź (2017)

\begin{tabular}{lll}
\hline Nr & $\begin{array}{c}\text { Typ cyrkulacji } \\
\text { powietrza }\end{array}$ & \multicolumn{1}{c}{ Panująca sytuacja synoptyczna } \\
\hline 1 & $\mathrm{Na}$ & sytuacja antycyklonalna - adwekcja powietrza z północy \\
2 & $\mathrm{NEa}$ & sytuacja antycyklonalna - adwekcja powietrza z północnego wschodu \\
3 & Ea & sytuacja antycyklonalna - adwekcja powietrza ze wschodu \\
4 & Sea & sytuacja antycyklonalna - adwekcja powietrza z południowego wschodu \\
5 & Sa & sytuacja antycyklonalna - adwekcja powietrza z południa \\
6 & SWa & sytuacja antycyklonalna - adwekcja powietrza z południowego zachodu \\
7 & Wa & sytuacja antycyklonalna - adwekcja powietrza z zachodu \\
8 & NWa & sytuacja antycyklonalna - adwekcja powietrza z północnego zachodu \\
9 & Ca & sytuacja antycyklonalna - centrum wyżu barycznego \\
10 & Ka & sytuacja antycyklonalna - klin wysokiego ciśnienia lub wał (grzbiet) \\
11 & Nc & baryczny \\
12 & NEc & sytuacja cyklonalna - adwekcja powietrza z północy \\
13 & Ec & sytuacja cyklonalna - adwekcja powietrza z północnego wschodu \\
14 & Sec & sytuacja cyklonalna - adwekcja powietrza z południowego wschodu \\
15 & Sc & sytuacja cyklonalna - adwekcja powietrza z południa \\
16 & SWc & sytuacja cyklonalna - adwekcja powietrza z południowego zachodu \\
17 & Wc & sytuacja cyklonalna - adwekcja powietrza z zachodu \\
18 & $\mathrm{NWc}$ & sytuacja cyklonalna -adwekcja powietrza z północnego zachodu \\
19 & $\mathrm{Cc}$ & sytuacja cyklonalna - centrum niżu barycznego \\
20 & $\mathrm{Bc}$ & sytuacja cyklonalna - zatoki niskiego ciśnienia lub bruzdy baryczne \\
21 & $\mathrm{X}$ & nóżne kierunki przepływu mas powietrza) \\
\hline & &
\end{tabular}

\section{REZULTATY BADAŃ}

Dobowe stężenie PM10 w latach 2012-2016 oraz cykl dobowy zanieczyszczeń w roku i półroczach

Na rycinie 2 przedstawiono przebieg wartości stężenia PM10 dla wielolecia 2012-2016. Zauważa się, że najwyższe stężenia tego pyłu w powietrzu odnotowano w okresie zimowym, natomiast najniższe latem. Najwyższa średnia dobowa wartość stężenia PM10 wynosząca $66,97 \mu \mathrm{g} / \mathrm{m}^{3}$ wystąpiła 12 lutego, najniższa - 13,64 $\mu \mathrm{g} / \mathrm{m}^{3} 8 \mathrm{kwietnia.} \mathrm{Zauważa} \mathrm{się,} \mathrm{że} \mathrm{koncentracja} \mathrm{stężenia} \mathrm{PM10}$ wykazuje wyraźnie cykliczność w ciągu roku polegającą na wzroście wartości w chłodniejszej części roku i spadku w cieplejszej, z minimum w maju i czerwcu. 


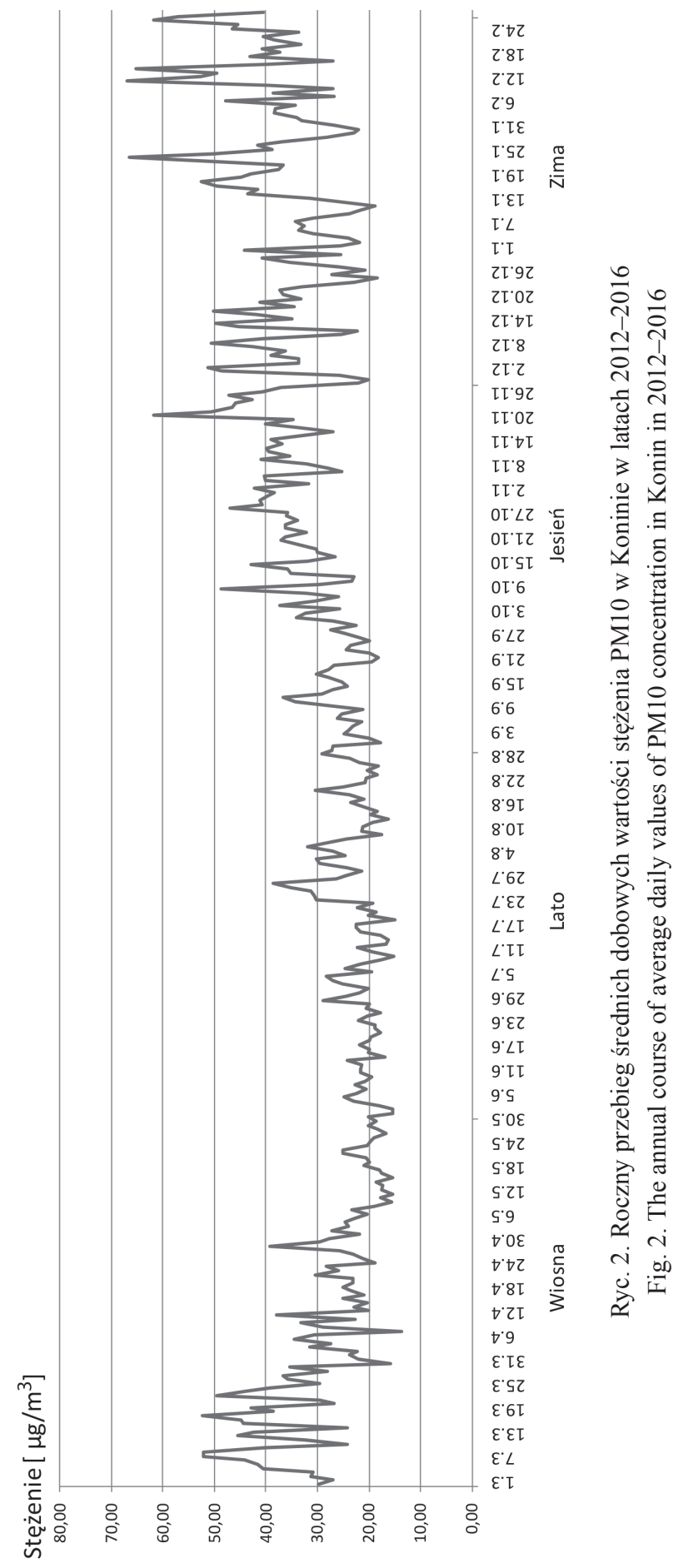


Wyraźną cykliczność stężenia PM10 zauważa się również w ciągu doby (ryc. 3). Najwyższe stężenia pyłu w cyklu dobowym występują o godzinie 1.00, a najniższe o 16.00. Odnotowuje się szybki wzrost stężenia po wystąpieniu minimum dobowego aż do maksimum dobowego i znacznie wolniejszy spadek stężenia od godziny z maksimum do godziny z minimum. Wskazuje to na zależność tego cyklu od temperatury powietrza, co świadczy o dominującym wpływie emisji niskiej na stężenie zanieczyszczeń.

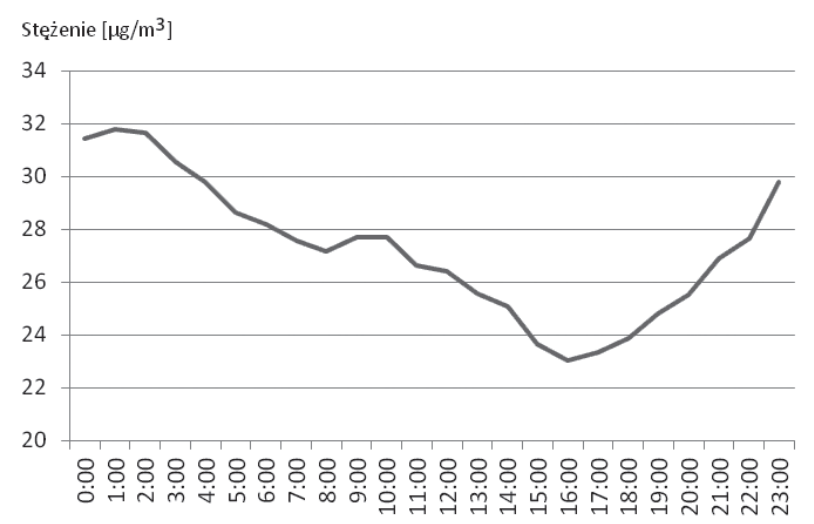

Ryc. 3. Dobowy przebieg stężenia PM10 w Koninie w latach 2012-2016

Fig. 3. The daily course of the PM10 concentration in Konin in 2012-2016

Na rycinie 4 przedstawiono dobowe przebiegi stężenia pyłu zawieszonego dla ciepłej i chłodnej połowy roku. Wykres dla ciepłej pory roku charakteryzuje się znaczącym wzrostem stężenia pyłu zawieszonego w godzinach od 7.00 do 9.00, co spowodowane jest zwiększonym ruchem samochodowym i większą emisją splin (Czernecki i in. 2016). Wykres przedstawiający dobowy przebieg stężenia pyłu zawieszonego podczas chłodnej pory roku charakteryzuje się wyraźnym wzrostem stężenia pyłu w godzinach wieczornych (od 18.00 do 0.00 ). Związane jest to z rozpoczęciem procesu grzewczego, który sprawia, że w godzinach wieczornych następuje silniejsza emisja PM10 do atmosfery (Czernecki i in. 2016).

$\mathrm{Na}$ obu wykresach zauważa się tendencję do zmniejszania stężenia pyłu zawieszonego w powietrzu w ciągu dnia. W porze ciepłej w godzinach od 10.00 do 18.00 , a w porze chłodnej od 3.00 do 16.00 . Większy spadek stężenia pyłu występuje w ciepłej porze roku.

Według Prządka i in. (2012) czynniki meteorologiczne silnie wpływają na stężenie pyłu zawieszonego 10 szczególnie w cieplejszej porze roku, kiedy najsilniejszą korelację otrzymano w zestawieniu z natężeniem opadu, temperaturą powietrza oraz natężeniem promieniowania słonecznego. 


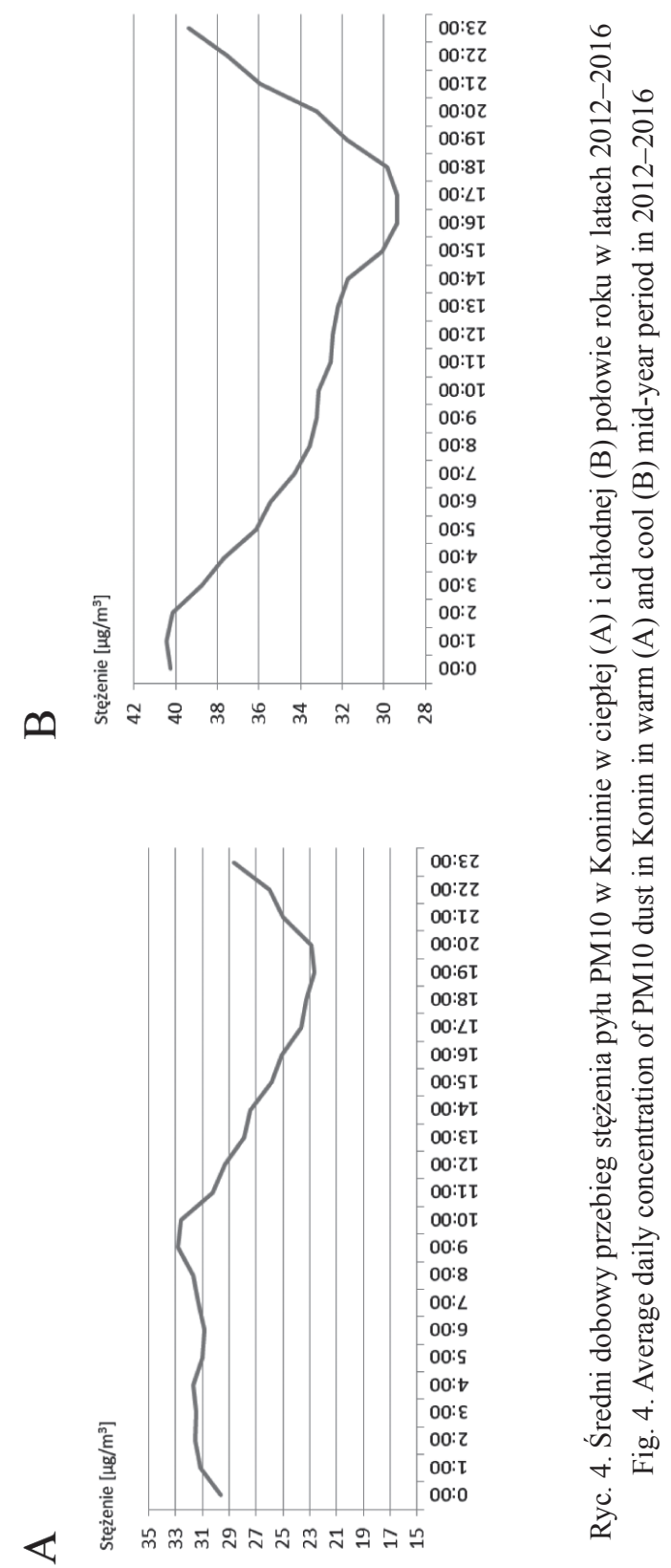



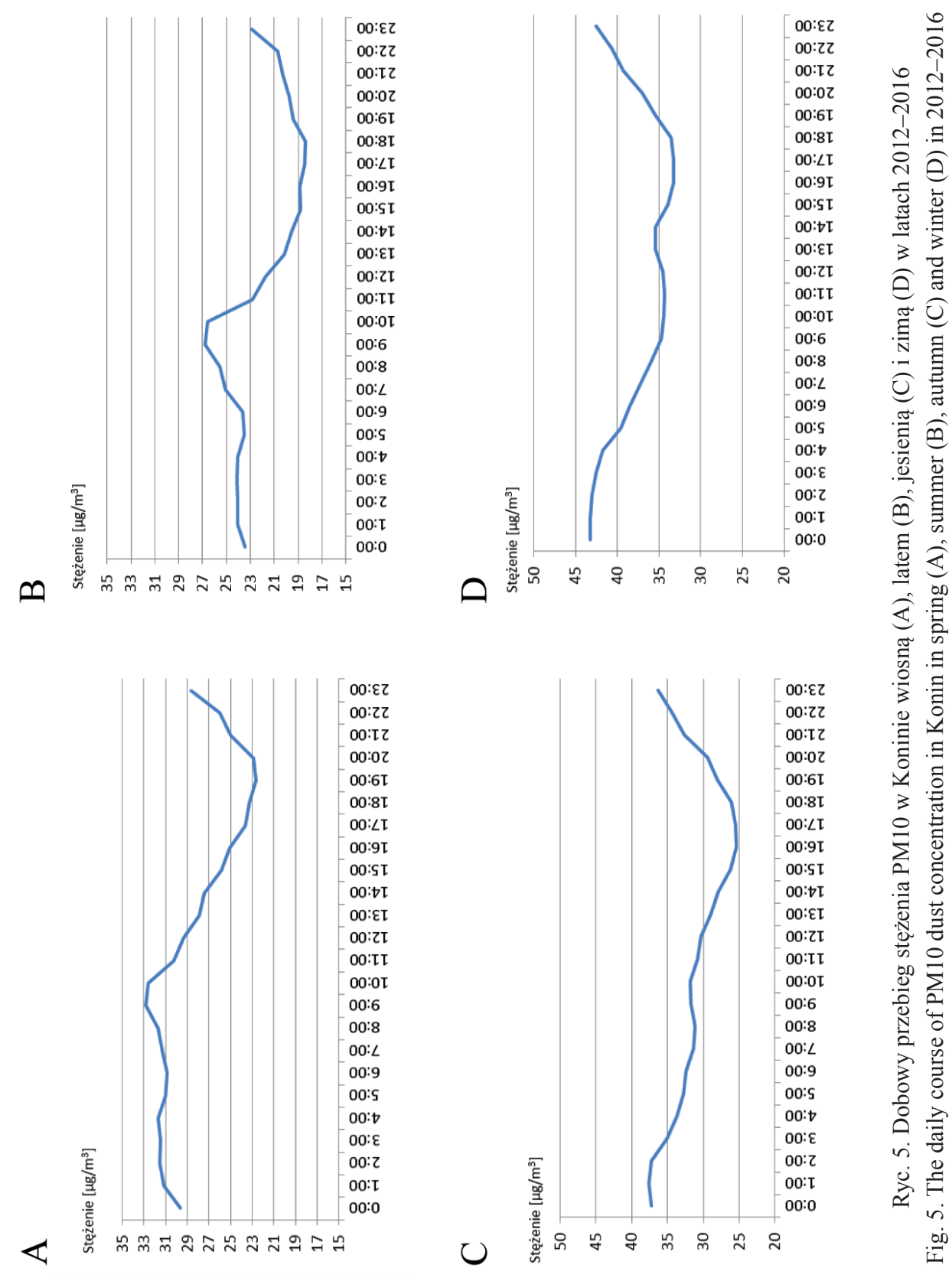


\section{STĘŻENIE PM10 W SEZONACH ROKU}

Na rycinie 5A pokazano przebieg dobowego stężenia pyłu zawieszonego w okresie wiosennym. Najwyższe stężenia występują o godzinie 9.00 i 10.00, odpowiednio: $32,83 \mu \mathrm{g} / \mathrm{m}^{3}$ oraz $32,58 \mu \mathrm{g} / \mathrm{m}^{3}$. Natomiast minimalne wartości stężenia pyłu zawieszonego odnotowano w godzinach wieczornych, tj. o 19.00 i 20.00 , odpowiednio: $22,69 \mu \mathrm{g} / \mathrm{m}^{3}$ i $22,86 \mu \mathrm{g} / \mathrm{m}^{3}$.

Z przebiegu krzywej wartości stężenia PM10 w ciągu lata wynika, że podobnie jak w okresie wiosennym maksymalne wartości przypadają na godzinę 9.00 i 10.00 i wynoszą odpowiednio: $26,81 \mu \mathrm{g} / \mathrm{m}^{3}$ oraz $26,6 \mu \mathrm{g} / \mathrm{m}^{3}$ (ryc. 5B) Minimalne wartości stężenia pyłu zawieszonego odnotowano w godzinach 17.00 i 18.00 w wysokości około $18,4 \mu \mathrm{g} / \mathrm{m}^{3}$.

Maksymalne wartości stężenia PM10 latem przypadają na godziny poranne (9.00-10.00) po wyraźnym wzroście od godziny 6.00. Przyczyną takiej sytuacji jest poranny szczyt komunikacyjny. Najniższe wartości stężenia pyłów zawieszonych latem odnotowuje się w godzinach $14.00-19.00 \mathrm{z}$ minimum na poziomie 18 $\mu \mathrm{g} / \mathrm{m}^{3}$ o godzinie 18.00 .

W okresie jesiennym wzrost związany z porannym szczytem komunikacyjnym jest już ledwie widoczny, a zaczyna przeważać cykl dobowy związany z emisją niską (ryc. 5C).

Maksymalne wartości stężenia PM10 przypadają na godzinę 0.00 i 1.00 i wynoszą odpowiednio: $37,62 \mu \mathrm{g} / \mathrm{m}^{3}$ oraz $37,28 \mu \mathrm{g} / \mathrm{m}^{3}$, a najniższe występują godzinach $14.00 \mathrm{i} 19.00 \mathrm{z}$ minimum na poziomie $25,4 \mu \mathrm{g} / \mathrm{m}^{3} \mathrm{w}$ godzinach $17.00-18.00$.

Dobowy cykl stężenia PM10 zimą wskazuje na występowanie przez całą dobę najwyższych w ciągu roku wartości zanieczyszczeń (ryc. 5D). Maksymalne stężenie na poziomie $43,2 \mu \mathrm{g} / \mathrm{m}^{3}$ występuje o godzinie $0.00 \mathrm{i} 1.00$, natomiast minimalne o wartościach $33,27 \mu \mathrm{g} / \mathrm{m}^{3}$ oraz $33,26 \mu \mathrm{g} / \mathrm{m}^{3}$ odpowiednio o 16.00 i 17.00 .

Podobny przebieg dobowy stężenia pyłu zawieszonego 10 . występuje jesienią i zimą (ryc. 5C i 5D). Jednak dobowy przebieg zimowy przedstawia o około $6 \mu \mathrm{g} /$ $\mathrm{m}^{3}$ wyższe stężenia pyłu zawieszonego niż dobowy przebieg jesienny. Różnica w tym przypadku wynika z temperatury powietrza (Ćwiek, Majewski 2015).

\section{GODZINOWE WARTOŚCI PM10 W LATACH 2012-2016}

Stosunkowo krótki okres badawczy wynikający z zakresu danych źródłowych możliwych do wykorzystania nie pozwala na szerszą analizę trendów w zmianach stężenia PM10, a jedynie na podjęcie próby oszacowania tej zmienności na podstawie wartości z kilku ostatnich lat. W tabeli 2 zestawiono dane dotyczące średniego godzinowego stężenia PM10 dla lat 2012-2016. Wartości stężeń pyłu z roku 2015 są dużo niższe niż w pozostałych latach. W tabeli zaznaczono dane dotyczące maksymalnych (kolorem czerwonym) i minimalnych (kolorem zielonym) 
stężeń pyłu zawieszonego $10 \mathrm{w}$ ciągu całego badanego okresu. Najwyższe wartości z wielolecia przypadają na godziny $0.00,1.00$ i $2.00 \mathrm{w}$ roku 2014 i wynoszą odpowiednio: $35,82 \mu \mathrm{g} / \mathrm{m}^{3}, 36,34 \mu \mathrm{g} / \mathrm{m}^{3}$ i $36,3 \mu \mathrm{g} / \mathrm{m}^{3}$. Najniższe wartości stężeń średnich godzinowych odnotowano o $8.00\left(11,4 \mu \mathrm{g} / \mathrm{m}^{3}\right)$ i $9.00\left(12,35 \mu \mathrm{g} / \mathrm{m}^{3}\right)$ oraz po południu - godzina $16.00\left(12,35 \mu \mathrm{g} / \mathrm{m}^{3}\right)$.

Tabela 3. Średnie godzinowe wartości stężenia PM10 w Koninie w latach 2012-2016

Table 3. Average hourly concentration values of PM10 in Konin in 2012-2016

\begin{tabular}{|c|c|c|c|c|c|}
\hline & 2012 & 2013 & 2014 & 2015 & 2016 \\
\hline 00:00:00 & 34,75 & 32,65 & 35,82 & 23,82 & 30,19 \\
\hline 01:00:00 & 35,64 & 33,38 & 36,34 & 22,92 & 30,70 \\
\hline 02:00:00 & 35,67 & 33,19 & 36,30 & 22,38 & 30,79 \\
\hline 03:00:00 & 34,78 & 32,64 & 35,14 & 19,50 & 30,55 \\
\hline 04:00:00 & 34,60 & 32,58 & 34,50 & 17,78 & 29,50 \\
\hline 05:00:00 & 33,37 & 31,30 & 33,35 & 16,20 & 28,86 \\
\hline 06:00:00 & 33,11 & 31,29 & 32,81 & 15,30 & 28,31 \\
\hline 07:00:00 & 32,03 & 31,52 & 33,11 & 12,73 & 28,36 \\
\hline 08:00:00 & 31,43 & 31,54 & 33,20 & 11,40 & 28,25 \\
\hline 09:00:00 & 32,31 & 32,14 & 33,08 & 12,35 & 28,65 \\
\hline $10: 00: 00$ & 32,36 & 31,81 & 33,03 & 12,83 & 28,37 \\
\hline 11:00:00 & 29,27 & 30,14 & 31,97 & 14,90 & 26,88 \\
\hline $12: 00: 00$ & 29,12 & 29,85 & 31,49 & 16,10 & 25,47 \\
\hline 13:00:00 & 27,98 & 29,67 & 30,65 & 15,48 & 24,07 \\
\hline $14: 00: 00$ & 27,69 & 29,07 & 30,12 & 15,08 & 23,44 \\
\hline $15: 00: 00$ & 26,61 & 26,81 & 28,64 & 13,38 & 22,75 \\
\hline $16: 00: 00$ & 26,43 & 26,40 & 27,76 & 12,35 & 22,17 \\
\hline 17:00:00 & 26,11 & 26,17 & 26,93 & 15,73 & 21,83 \\
\hline 18:00:00 & 26,30 & 26,53 & 26,65 & 17,70 & 22,09 \\
\hline 19:00:00 & 27,94 & 27,32 & 27,67 & 18,25 & 22,87 \\
\hline 20:00:00 & 28,38 & 28,19 & 28,12 & 18,50 & 24,51 \\
\hline 21:00:00 & 31,37 & 29,93 & 29,98 & 17,28 & 26,02 \\
\hline $22: 00: 00$ & 31,81 & 30,77 & 31,28 & 16,55 & 27,75 \\
\hline 23:00:00 & 34,40 & 32,52 & 34,11 & 18,78 & 29,19 \\
\hline
\end{tabular}

Kolor czerwony - wartości maksymalne, kolor zielony - wartości minimalne.

Red color - maximum values, green - minimal values.

\section{ANALIZA I KORELACJA STĘŻEŃ PM10 Z TYPAMI CYRKULACJI ATMOSFERYCZNEJ}

W tabeli 4 i 5 przedstawiono zestawienie średniego miesięcznego i średniego sezonowego stężenia pyłu zawieszonego w powietrzu PM10 z typami cyrkulacji 
atmosferycznej w latach 2012-2016. W tabelach zaznaczono maksymalne (kolorem czerwonym) i minimalne (kolorem zielonym) stężenia oraz wartości pośrednie przechodzące od koloru czerwonego do koloru zielonego. Puste okna tabeli świadczą o braku typu cyrkulacji w danym miesiącu.

W przypadku tabeli 4 dotyczącej średnich miesięcznych stężeń PM10 minimalne wartości wynoszące $6,95 \mu \mathrm{g} / \mathrm{m}^{3}$ wystąpiły w maju, gdy badany obszar znalazł się w centrum wyżu barycznego. Sytuacje wyżowe w cieplejszych miesiącach charakteryzują się niewielkim zachmurzeniem, wysoką temperaturą powietrza i ruchami konwekcyjnymi, co sprzyja niskim stężeniem pyłu zawieszonego (Dąbrowski, Jaguś 2003). Maksymalne średnie miesięczne stężenie PM10 odnotowano $\mathrm{w}$ grudniu, jako skutek oddziaływania powietrza napływającego z północy podczas sytuacji cyklonalnej, wynosiło $84,93 \mu \mathrm{g} / \mathrm{m}^{3}$.

Z tabeli 3 wynika, że najczęściej niższe stężenia pyłu zawieszonego występują w momencie adwekcji mas powietrza z zachodu (Wc), północnego zachodu (NWc) i południowego zachodu (SWc) w sytuacji cyklonalnej. Niskie wartości występują również podczas oddziaływania powietrza napływającego z północy (Sa), północnego zachodu (SWa) oraz z zachodu (Wa) w sytuacji antycyklonalnej i w centrum wyżu barycznego $(\mathrm{Ca})$ w miesiącach letnich. Wyższe stężenia pyłu zawieszonego przypadają na miesiące zimowe w momencie wystąpienia klina wysokiego ciśnienia (Ka) oraz podczas napływu mas powietrza z południa (Sa), południowego zachodu (SWa) i południowego wschodu (SEa) w sytuacji antycyklonalnej oraz podczas adwekcji powietrza $\mathrm{z}$ południowego wschodu (SEc) w sytuacji cyklonalnej.

W tabeli 4 zestawiono średnie sezonowe stężenia PM10 z typami cyrkulacji atmosferycznej. Najwyższe średnie sezonowe stężenie pyłu występuje zimą pod wpływem adwekcji mas powietrza ze wschodu (Ec) i wynosi $56,33 \mu \mathrm{g} / \mathrm{m}^{3}$, natomiast najniższe $\left(12,24 \mu \mathrm{g} / \mathrm{m}^{3}\right)$ podczas oddziaływania powietrza napływającego z północnego wschodu (NEc) w sytuacji cyklonalnej. Z tabeli wynika, że wyższe średnie sezonowe stężenia występują zazwyczaj zimą, najniższe zaś latem. Zauważa się wpływ niżu barycznego $(\mathrm{Cc})$ oraz oddziaływanie adwekcji mas powietrza z zachodu (Wc) i północnego zachodu (NWc) w sytuacji cyklonalnej na niskie średnie stężenie pyłu zawieszonego w ciągu całego roku.

Na rycinach 6 i 7 przedstawiono mapy sytuacji synoptycznych, które uzyskano ze strony internetowej $<$ wetter3.de $>$. W opracowaniu wykorzystano mapy sporządzone dla dni, w których stężenie pyłu zawieszonego 10 było najwyższe i najniższe. Wyznaczono 20 dni z maksymalnymi i 20 dni z minimalnymi wartościami stężenia pyłu, dla których pobrano mapy synoptyczne. Spośród 40 wybrano 12 rycin (sześć $\mathrm{z}$ dni z wartościami maksymalnymi i sześć z dni z wartościami minimalnymi), na których pokazano najbardziej charakterystyczne sytuacje synoptyczne dla występowania ekstremalnych stężeń PM10 w Koninie. 

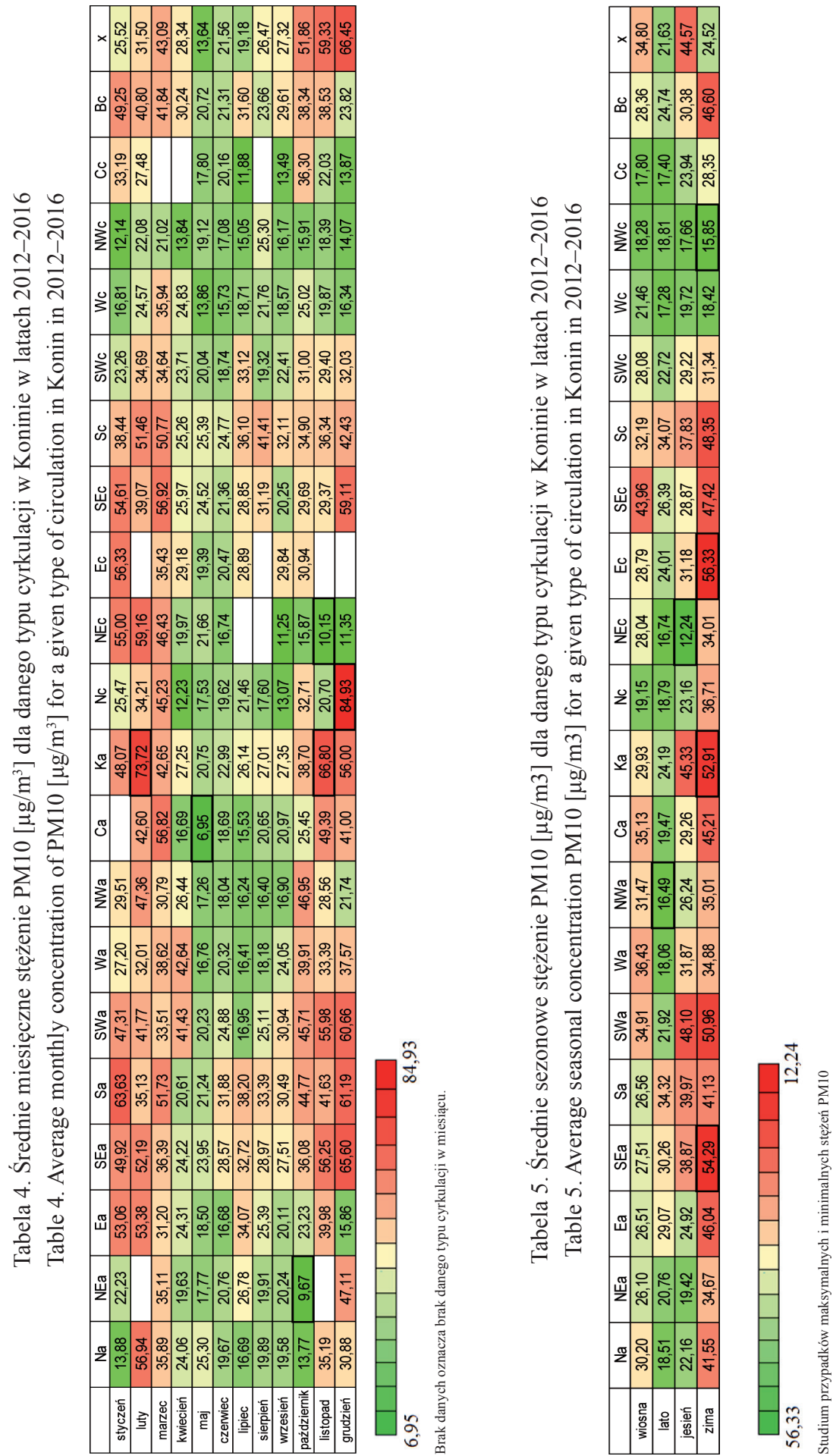

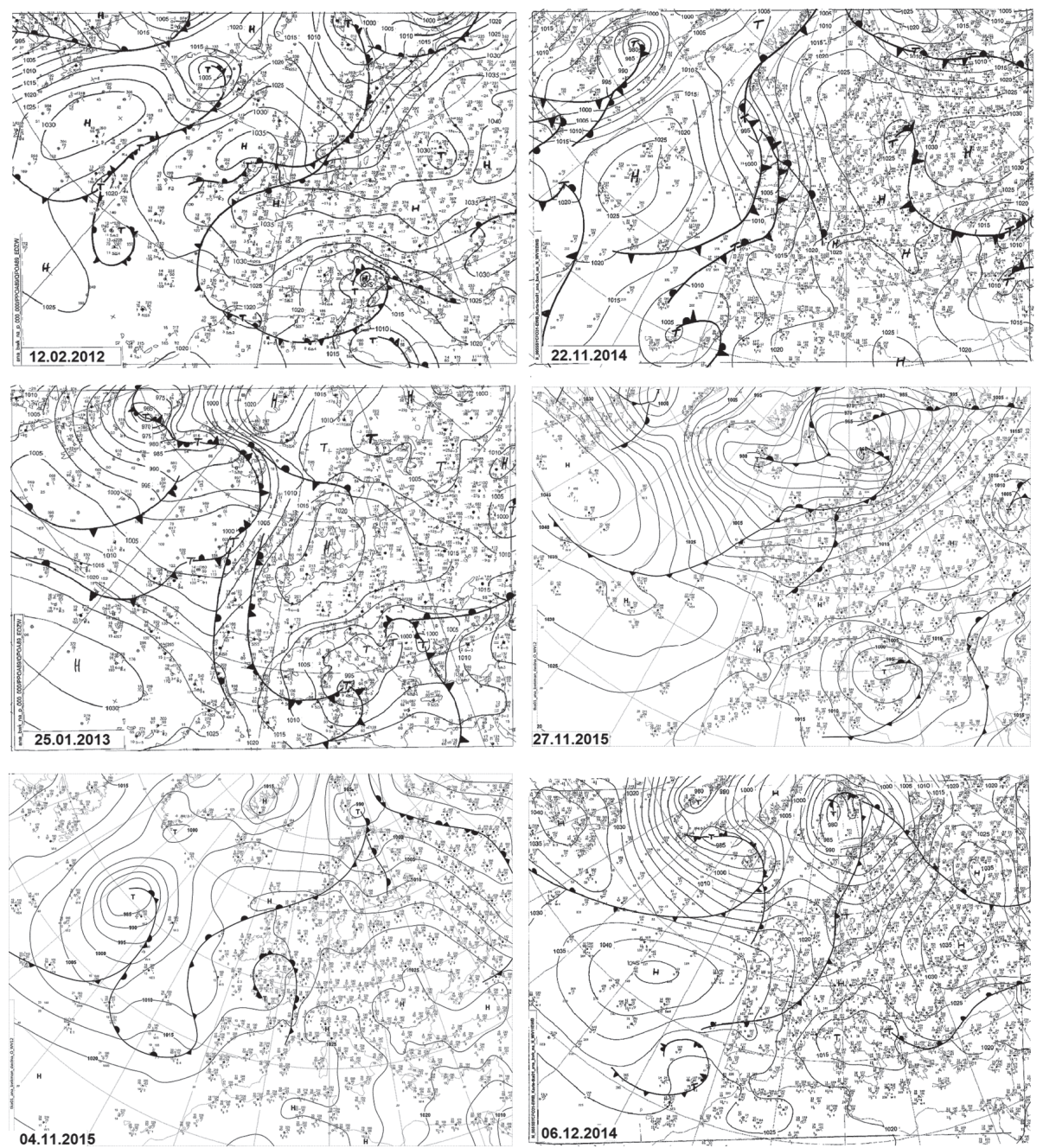

Ryc. 6. Mapy synoptyczne dla wybranych dni o najwyższym stężeniu PM10

Fig. 6. Synoptic maps for selected days with the highest concentration of PM10

\section{ANALIZA SYTUACJI SYNOPTYCZNYCH WPŁYWAJĄCYCH NA WARTOŚCI MAKSYMALNE PM10}

W Koninie w latach 2012-2016 przekroczenia normy stężeń pyłu zawieszonego w powietrzu wynoszącej $50 \mu \mathrm{g} / \mathrm{m}^{3}$ wystąpiły w ciągu 209 dni. Do szczegółowej analizy przypadków podwyższonych stężeń PM10 wybrano sytuacje, które charakteryzują się nie tylko znaczną kondensacją pyłu zawieszonego w powietrzu, ale także specyficznymi warunkami meteorologicznymi. 

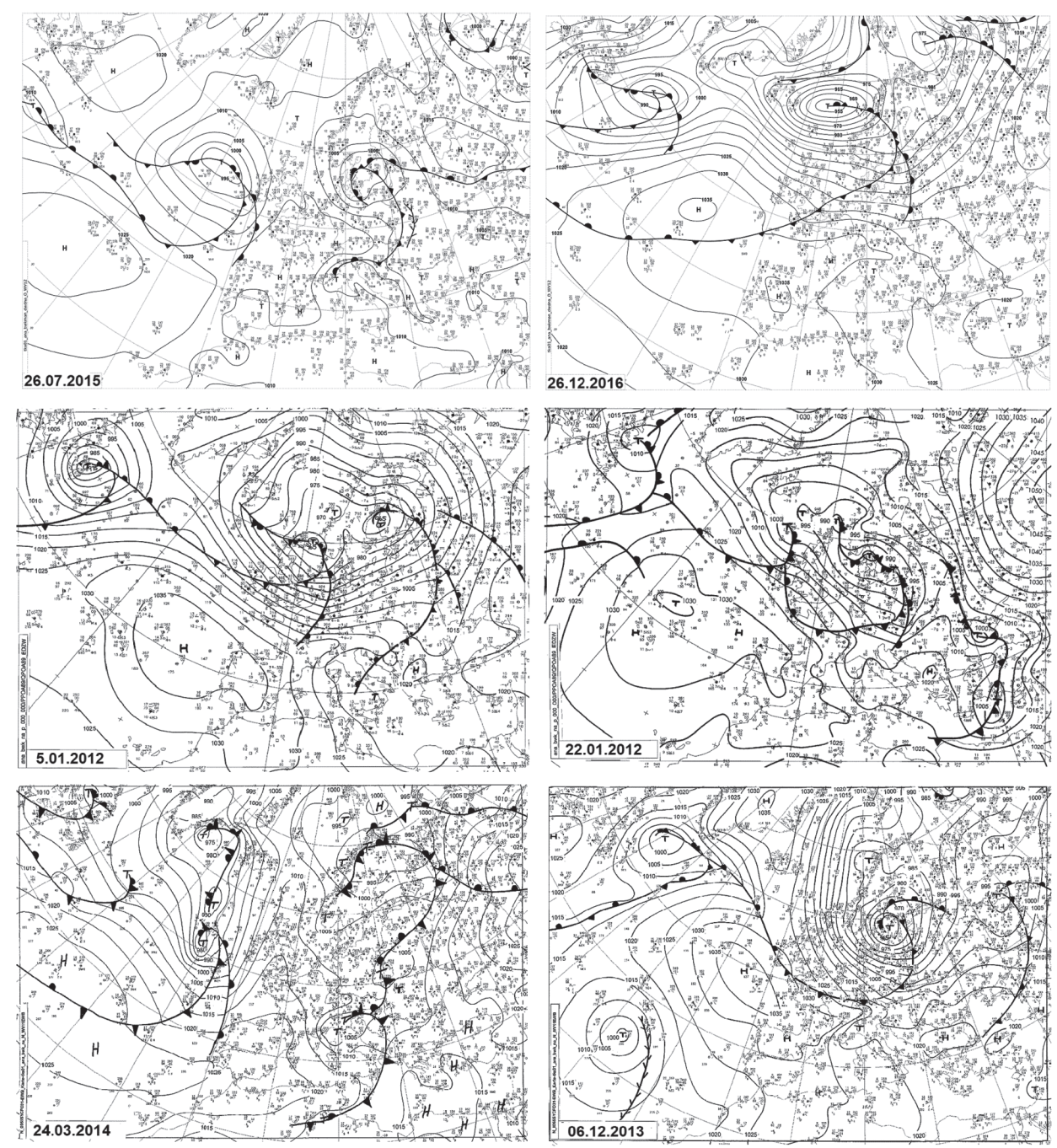

Ryc. 7. Mapy synoptyczne dla wybranych dni o najniższym stężeniu PM10

Fig. 7. Synoptic maps for selected days with the lowest concentration of PM10

W tabeli 6 zestawiono dni, w których odnotowano ekstremalnie wysokie stężenia PM10 w latach 2012-2016, wyższe od 99. percentyla wartości średnich dobowych, oraz występujące wtedy typy cyrkulacji atmosferycznej. Zauważyć można, że większość stężeń maksymalnych występuje w miesiącach jesiennych oraz zimowych (jedynie dwa przypadki wiosną w marcu). Z tabeli 6 wynika, że przeważająca część najwyższych stężeń pyłu zawieszonego wystąpiła w momencie oddziaływania typów cyrkulacji o oznaczeniu 1-10, czyli podczas antycyklonalnej sytuacji synoptycznej. Jedynie pięć przypadków dotyczyło stężeń odnotowanych w obecności typów cyrkulacji cechujących się 
sytuacją cyklonalną. Spośród 20 dni z najwyższymi wartościami stężeń PM10 najczęściej występował typ cyrkulacji 10-Ka, którego cechuje obecność klina wysokiego ciśnienia lub wału barycznego.

Tabela 6. Dni z najwyższymi stężeniami PM10 i typami cyrkulacji atmosferycznej

Table 6. Days with the highest concentrations of PM10 and types of atmospheric circulation

\begin{tabular}{|c|c|c|c|c|}
\hline Rok & Miesiąc & Dzień & TC & PM10 \\
\hline 2012 & 1 & 5 & Wc & 1,93 \\
\hline 2015 & 7 & 26 & Wc & 2,26 \\
\hline 2016 & 12 & 26 & Wc & 2,88 \\
\hline 2012 & 6 & 2 & Wc & 3,62 \\
\hline 2012 & 1 & 3 & Wa & 4,27 \\
\hline 2012 & 1 & 4 & Wc & 4,99 \\
\hline 2012 & 1 & 13 & NWC & 5,20 \\
\hline 2012 & 1 & 14 & Nc & 5,25 \\
\hline 2014 & 4 & 9 & NWc & 5,39 \\
\hline 2016 & 2 & 22 & Wc & 5,43 \\
\hline 2015 & 3 & 30 & Bc & 5,77 \\
\hline 2012 & 1 & 22 & Wc & 5,83 \\
\hline 2014 & 12 & 22 & Wc & 5,93 \\
\hline 2016 & 12 & 25 & Wc & 6,04 \\
\hline 2014 & 3 & 24 & Nc & 6,05 \\
\hline 2013 & 12 & 6 & NWc & 6,09 \\
\hline 2016 & 10 & 6 & Bc & 6,15 \\
\hline 2014 & 12 & 23 & Wc & 6,15 \\
\hline 2015 & 7 & 20 & NWc & 6,18 \\
\hline & & & & \\
\hline
\end{tabular}

Mapy synoptyczne z sytuacjami meteorologicznymi, które sprzyjają ekstremalnie wysokim stężeniom PM10, przedstawiono na rycinie 6. Są to sytuacje, kiedy badany obszar znajduje się w zasięgu oddziaływania wyżu barycznego. Znaczący wpływ wysokiego ciśnienia na stężenie pyłu zauważa się, porównując sytuacje synoptyczne z dnia 12.02.2012 i 22.11.2014 z pozostałymi. Na dwóch pierwszych mapach pokazano układy baryczne, w których ciśnienie atmosferyczne w okolicach Konina uzyskuje najwyższe wartości (odpowiednio: $1035 \mathrm{hPa}$ i $1025 \mathrm{hPa}$ ). Stężenie pyłu zawieszonego w tych dniach wynosiło odpowiednio: $153,65 \mu \mathrm{g} / \mathrm{m}^{3}$ i $151,42 \mu \mathrm{g} / \mathrm{m}^{3}$, w innych przypadkach to stężenie było już dużo niższe (średnio o $20 \mu \mathrm{g} / \mathrm{m}^{3}$ ). Obszar badań w dniach przedstawionych na poniższych mapach znajdował się pod wpływem klina wysokiego ciśnienia (Ka). Ciśnienie atmosferyczne w Koninie w dniach, w których panują najwyższe stężenia pyłu zawieszonego, wynosi od 1015-1035 hPa. Na mapach zauważa się również brak występowania nad badanym obszarem frontów atmosferycznych, z którymi wiąże się m.in. obecność silnego wiatru i opadów atmosferycznych, które wpływają na obniżenie stężenia pyłu zawieszonego (Drzeniecka-Osiadacz, Netzel 2010). 


\section{ANALIZA SYTUACJI SYNOPTYCZNYCH WPŁYWAJĄCYCH NA WARTOŚCI MINIMALNE}

W tabeli 7 zestawiono dni, w których odnotowano najniższe stężenia PM10 w latach 2012-2016 oraz występujące wtedy typy cyrkulacji atmosferycznej. Zauważyć można, że podobnie jak w przypadku stężeń maksymalnych większość stężeń minimalnych występuje w miesiącach zimowych (jedynie sześć przypadków wiosną i latem).

Przeważająca liczba przypadków najniższych stężeń pyłu zawieszonego wystąpiła podczas cyklonalnej sytuacji synoptycznej. Jeden przypadek dotyczył sytuacji antycyklonalnej - 4,27 $\mu \mathrm{g} / \mathrm{m}^{3}$ (tab. 7).

Spośród wszystkich dni z najniższymi wartościami stężeń PM10 najczęściej występował typ cyrkulacji Wc z adwekcją powietrza z zachodu oraz NWc cechujący się napływem mas powietrza z północnego zachodu.

Najniższe stężenie pyłu zawieszonego $\left(1,93 \mu \mathrm{g} / \mathrm{m}^{3}\right)$ odnotowano 5.01.2012 r. podczas panowania sytuacji cyklonalnej z adwekcją powietrza z zachodu. Pod wpływem działania tego samego rodzaju cyrkulacji atmosferycznej znajdował się obszar w trzech kolejnych analizowanych dniach o równie niskim stężeniu pyłu $\left(2,26 \mu \mathrm{g} / \mathrm{m}^{3}, 2,88 \mu \mathrm{g} / \mathrm{m}^{3}, 3,62 \mu \mathrm{g} / \mathrm{m}^{3}\right)$.

Tabela 7. Dni z najniższymi stężeniami PM10 i typami cyrkulacji atmosferycznej

Table 7. Days with the lowest concentrations of PM10 and types of atmospheric circulation

\begin{tabular}{|c|c|c|c|c|}
\hline Rok & Miesiąc & Dzień & TC & PM10 \\
\hline 2012 & 1 & 5 & Wc & 1,93 \\
\hline 2015 & 7 & 26 & Wc & 2,26 \\
\hline 2016 & 12 & 26 & Wc & 2,88 \\
\hline 2012 & 6 & 2 & Wc & 3,62 \\
\hline 2012 & 1 & 3 & Wa & 4,27 \\
\hline 2012 & 1 & 4 & Wc & 4,99 \\
\hline 2012 & 1 & 13 & NW & 5,20 \\
\hline 2012 & 1 & 14 & Nc & 5,25 \\
\hline 2014 & 4 & 9 & NWc & 5,39 \\
\hline 2016 & 2 & 22 & Wc & 5,43 \\
\hline 2015 & 3 & 30 & Bc & 5,77 \\
\hline 2012 & 1 & 22 & Wc & 5,83 \\
\hline 2014 & 12 & 22 & Wc & 5,93 \\
\hline 2016 & 12 & 25 & Wc & 6,04 \\
\hline 2014 & 3 & 24 & Nc & 6,05 \\
\hline 2013 & 12 & 6 & NWc & 6,09 \\
\hline 2016 & 10 & 6 & Bc & 6,15 \\
\hline 2014 & 12 & 23 & Wc & 6,15 \\
\hline 2015 & 7 & 20 & NWc & 6,18 \\
\hline & & & & \\
\hline
\end{tabular}


Na rycinie 7 pokazano mapy synoptyczne sytuacji meteorologicznych, które sprzyjają najmniejszej kumulacji PM10. To sytuacje synoptyczne, w których badany obszar znajduje się w zasięgu niżu barycznego. Najbardziej korzystne warunki występują podczas adwekcji mas powietrza z zachodu w sytuacji cyklonalnej przedstawionej na pierwszych czterech mapach synoptycznych. Na dwóch ostatnich mapach przedstawiono analizowany obszar w momencie napływu powietrza z północy $(\mathrm{Nc})$ i północnego zachodu (NWc) w sytuacji cyklonalnej, które również nie sprzyjają wysokim stężeniom pyłu zawieszonego.

Ciśnienie atmosferyczne w Koninie w dniach, w których panują najniższe stężenia pyłu zawieszonego, wynosi od $990 \mathrm{hPa}$ do $1115 \mathrm{hPa}$. Na mapach zaznaczono również fronty atmosferyczne, których wystąpienie wpłynęło na oczyszczenie powietrza (Drzeniecka-Osiadacz, Netzel 2010).

\section{DYSKUSJA I PODSUMOWANIE}

Z przeprowadzonych analiz stężeń PM10 na obszarze Konina w latach 20122016 wynika, że ciepła połowa roku charakteryzuje się znaczącym wzrostem stężenia pyłu w godzinach od 7.00 do 9.00. Spowodowane jest to prawdopodobnie zwiększonym ruchem samochodowym i większą emisją splin (Czernecki i in. 2016). Z kolei w półroczu chłodnym obserwuje się wyraźny wzrost stężenia pyłu w godzinach wieczornych i nocnych (od godziny 18.00 do 0.00 ). Związane jest to z rozpoczęciem procesu grzewczego, który sprawia, że w tym okresie doby następuje silniejsza emisja PM10 do atmosfery (Czernecki in. 2016). Najmniejsze stężenia pyłu zawieszonego w powietrzu w ciągu dnia odnotowano w półroczu ciepłym w godzinach od 10.00 do 18.00 , natomiast w chłodnej od 3.00 do 16.00 .

Z przeprowadzonych analiz wynika, że najwyższe wartości stężeń pyłu w Koninie występowały podczas panowania nad badanym obszarem układów wyżowych, najniższe zaś w sytuacjach cyklonalnych. W latach 2012-2016 szczególnie złą jakość powietrza odnotowano 12.02.2012 r. i 22.11.2014 r., za sprawą klina wysokiego ciśnienia, podczas którego w Koninie panowało bardzo wysokie ciśnienie i niska temperatura powietrza. Sprzyjające koncentracji pyłu zawieszonego są również masy powietrza napływające z południa, południowego wschodu i zachodu w sytuacji antycyklonalnej. Takie typy cyrkulacji atmosferycznej doprowadzają do wytworzenia stałej stratyfikacji powietrza, co w konsekwencji sprzyja powstaniu inwersji termicznych odpowiedzialnych za zwiększenie koncentracji pyłu zawieszonego PM10 (Radomski 2008). Według Chlebowskiej-Styś i Sówki (2015) tak ekstremalnie wysokie stężenia pyłu zawieszonego PM10 wynika również z faktu, że wystąpiły one w chłodnej porze roku podczas okresu grzewczego (Falkowska, Lewandowska 2009; Ćwiek, Majewski 2015; Jankowska, Pośniak 2006; Pietras 2015). W badanym okresie 
wystąpiło wiele dni z sytuacjami cyklonalnymi, które sprawiły, że stężenie PM10 osiągało najniższe wartości. Szczególnie czyste powietrze odnotowano 5.01.2012 r. podczas wpływu układu niżowego oraz adwekcji wilgotnych mas powietrza z zachodu, co zauważono również w badaniach dotyczących innych miast w Polsce (Koźmiński i in. 1998; Gioda i in. 2013).

\section{BIBLIOGRAFIA}

Cembrzyńska J., Krakowiak E., Brewczyński P.Z., 2012: Zanieczyszczenie powietrza pyłem zawieszonym PM10 oraz PM2,5 w warunkach silnej antropopresji na przyktadzie miasta Sosnowiec, Med. Środ., 15, 4, 31-38.

Chlebowska-Styś A., Sówka I., 2015: Trendy zmian stężenia pytów zawieszonych (PM10 i PM2,5) oraz benzo(a)piranu na przyktadzie wybranych miast wielkopolski, 40-53.

Czarnecka M., Kalbarczyk R., 2008: Warunki meteorologiczne kształtujące zmienność stężenia pytu zawieszonego na Pomorzu, Act. Agrophys., 11(2), 357-368.

Czernecki B., Półrolniczak M., Kolendowicz L., Marosz M., Kendzierski S., Pilguj N., 2016: Influence of the atmospheric conditions on PM10 concentrations in Poznań, Poland, Journ. of Atm. Chem., 74(1), 115-139.

Ćwiek K., Majewski G., 2015: The influence of meteorological factors on the development of air pollutants concentration - Cracow case study, Sc. Rev. - Eng. and Environmental Sc., 67, 2015, 54-66.

Dąbrowski D., Jaguś A., 2003: Występowanie układów barycznych, mas powietrza i frontów atmosferycznych nad regionem pienińskim. Pieniny - Przyr. i Czł., 8, 53-61

Drzeniecka A., Peryma J., Pyka J., Szczurek A., 2000: Wpływ warunków meteorologicznych na stężenie zanieczyszczeń powietrza w śródmieściu Wrocławia, Chem. i Inż.

Ekol., 7, 8/9, 865-882.

Drzeniecka-Osiadacz A., Netzel P., 2010: Wpływ warunków meteorologicznych oraz cyrkulacji atmosferycznej na stężenie PM10 we Wrocławiu, Proc. of ECOpole, 4(2), 343-349.

Falkowska L., Lewandowska A., 2009: Aerozole i gazy w atmosferze ziemskiej-zmiany globalne, Wyd. UG.

Fuksa D., Ciszyńska E., 2010: Analiza i prognoza zanieczyszczenia powietrza na przykładzie aglomeracji miejskiej Krakowa, <http://www.ptzp.org.pl/files/konferencje/kzz/artyk_ pdf_2010/51_Fuksa_D.pdf> [dostęp: 20.09.2018 r.].

Gioda A., Ventura L., Lima I., Luna A., 2013: Influence of meteorological parameters on air quality, EGU Gen. Assembly Conf. Abstracts, April, Vol. 15, 3256.

GIOŚ, 2017: Stan środowiska w Polsce, Sygnały 2016, Warszawa.

Jankowska E., Pośniak M., 2006: Występowanie pyłów w powietrzu otaczającym człowieka, Bezpieczeństwo Pr.: nauka i praktyka, 5, 16-19.

Koźmiński C., Bac S., Rojek M., 1998: Agrometeorologia, Wyd. Nauk. PWN, Warszawa.

Leśniok M., Małarzewski Ł., Niedźwiedź T., 2010: Classification of circulation types for Southern Poland with an application to air pollution concentration in Upper Silesia, Phys. and Chem. of the Earth, 35, 9-12, 516-522.

Niedźwiedź T., 1999: Rola cyrkulacji atmosfery w ksztaltowaniu przeptywu powietrza przez Bramę Morawska, [w:] M. Leśniok (red.), Materiały konferencyjne nt. „Zanieczyszczenia pyłowe atmosfery”, Cieszyn 19-20 listopada 1999, Pol. Tow. Miner., Pr. Spec., z. 15, Wyd. Nauk. Akapit, Kraków, 101-109.

Niedźwiedź T., 2006: Typologia cyrkulacji atmosfery dla Polski i metody określania regionalnych wskaźników cyrkulacji, Ann. Univ. Marie Curie-Skłodowska Lublin - Polonia Vol. 61, 38. 
Niedźwiedź T., 2017: Kalendarz typów cyrkulacji atmosfery dla Polski potudniowej-zbiór komputerowy, UŚ, Kated. Klimatol., Sosnowiec.

Oleniacz R., Bogacki M., Rzeszutek M., Kot A., 2014: Meteorologiczne determinanty jakości powietrza w Krakowie, [w:] J. Konieczyński (red.), Ochrona powietrza w teorii i praktyce, Inst. Podst. Inż. Środ. PAN, Zabrze 2014, 163-178.

Pietras B., 2015: Cyrkulacyjne uwarunkowania występowania wysokich stężeń pyłu zawieszonego w Krakowie, Bad. Fizjograf. Ser. A - Geogr. Fiz., 121-130.

Prządka Z., Degórska A., Skotak K. 2012: Zależność pomiędzy stężeniami metali ciężkich i pylu PM10 a parametrami meteorologicznymi w rejonie Puszczy Boreckiej w latach 2005-2011, Monit. Środ. Przyr., 13, 85-92.

Radomski J., 2008: Wpływ typów cyrkulacji na stężenie pyłu zawieszonego (PM10) w zimie na Wyżynie Ślaskiej, Probl. Ekol., 12(4), 207-210.

Rozporządzenie Ministra Środowiska z dnia 24 sierpnia 2012 r. w sprawie poziomów niektórych substancji w powietrzu (Dz.U. z 2012 r., poz. 1031).

$<$ www.powietrze.gios.gov.pl $>$ [20.09.2018 r.].

$<$ www.wetter3.de $>$ [20.09.2018 r.]. 